DOI: https://doi.org/10.11144/Javeriana.upsy16.3.pstj

\title{
Predictors of Support toward Transitional Justice Process in Chilean General Population Sample
}

\section{Predictores de apoyo hacia los procesos de justicia transicional en una muestra de población general chilena}

Received: 16 December 2013 | Accepted: 07 March 2017

\author{
Manuel Cárdenas Castro \\ Universidad de Valparaíso, Chile \\ ORCID: http://orcid.org/0000-0002-5484-0078 \\ DARÍo PÁEz \\ Universidad del País Vasco, España \\ Maitane Arnoso \\ Universidad del País Vasco, España \\ BERnARD Rimé \\ Université de Louvain
}

a Correspondance autor. E-mail: manuel.cardenas@uv.cl

To cite this article: Cárdenas Castro, M. C., D., \& Rimé, B. (2017). Predictors of support toward transitional justice process in chilean general population sample. Universitas Psychologica, 16(3), $1-11$.

https://doi.org/10.11144/Javeriana.upsy16.3.pstj

\begin{abstract}
The objective of the present study was to evaluate the predictors of attitudes toward transitional justice process (1991, National Truth and Reconciliation Commission). No studies that report on the variables that could predict a positive evaluation of TRC in the Chilean context are currently available. A logistic regression analysis based on original survey data from Chile $(\mathrm{N}=1267$ ) was carried out to evaluate the work of truth commissions as the dependent variable (in terms of "approval" and "disapproval"). Results reveal that predictors of favorable attitudes towards truth and reconciliation commissions (TRC) include emotions such as sadness and hope, TRC contribution to truth and to the construction of an inclusive history (and to a lesser extent to justice), high social sharing, perception of a positive social climate, high institutional trust, and positive perception of official apologies. People supporting TRC also agree with complementary reparation, suggesting that a positive attitude towards TRC and less prone to denial of the traumatic past. Keywords

Political violence; Transitional rituals; Truth and Reconciliation Commissions
\end{abstract}

\section{RESUMEN}

El objetivo del presente estudio fue evaluar un conjunto de variables predictoras del apoyo de los procesos de justicia transicional (Comisión Nacional de Verdad y Reconciliación, CNVR, 1991). Actualmente no disponemos de estudios que reporten las variables que predicen una valoración positiva de las dichas comisiones en Chile. Un análisis de regresión logística fue realizado con datos de una muestra de población general $(\mathrm{N}=1267)$ para evaluar el trabajo realizado por la Comisión (en términos de aprobación o rechazo). Los resultados indican que las emociones de tristeza y esperanza son buenas predictoras de actitudes favorables hacia el trabajo de la CNVR, así como el logro de los objetivos 
referidos a verdad, justicia y construcción de una historia integradora. Del mismo modo, altos niveles de compartición social de las experiencias, percepción del clima social como positivo, confianza institucional y una percepción positiva de las disculpas institucionales resultan buenos predictores de una positiva evaluación del trabajo de la CNVR. Las personas que a que valoran positivamente el trabajo de la comisión están más de acuerdo a su vez con las medidas de reparación y menos dispuestas a negar el pasado traumático.

Palabras clave

Violencia política; rituales transicionales; Comisiones de Verdad y Reconciliación

Truth and Reconciliation Commissions (TRC) are one of the transitional justice measures most widely used for moving from a violence climate produced by internal armed conflicts or military dictatorships to living peacefully together. These commissions can be understood as transitional rituals the goal of which is to implement a series of mechanisms so as to address human rights abuse. They are intended to consolidate norms and strengthen social cohesion so as to avoid future violence and recover institutional trust lost during periods of political violence (Beristain, Páez, Rimé, \& Kanyangara, 2010). Thus, the aim is peaceful and harmonious life among groups, leaving no room for impunity and with the intention of repairing the harm to victims, and to society as a whole, done by dictatorships or perpetuated by internal armed conflicts. There is evidence supporting the negative intra- and interpersonal effects of traumatic events such as collective violence (Rimé, Finkenauer, Luminet, Zech, \& Philippot, 1998).

TRC have been established in many countries to deal with serious human rights violations committed by dictatorship regimes or during internal armed conflicts. Since the 1970s, more than 30 official commissions have been set up in different parts of the world (Avruch, 2010). TRC are temporary bodies created to investigate, though not necessarily judge, human rights violations perpetrated by state agents and/ or armed opposition forces (Hayner, 2001). The common functions of TRC are: a) to make efforts to find the truth about the period of collective violence; b) to recognize and validate victims' suffering; c) to compensate those affected, both materially and symbolically; d) to contribute to the creation of an inclusive social memory oriented to the future; e) to avoid new violent events; and f) to seek justice. These functions can help to avoid revenge cycles and other war crimes, at the same time preventing the emergence of collective violence (Sikkink \& Bott-Walling, 2007), above all in cases where there is support for the TRC and appropriate institutional organization (Brahms, 2009).

\section{The National Truth and Reconciliation Commission in Chile}

The National Truth and Reconciliation Commission (NTRC) was created in April 1990 with a view to discover the truth about human rights violations by Chilean state agents between September 11th, 1973 (day of the military coup) and March 1990 (beginning of the transition to democracy). Its report was published in 1991. The purpose of the NTRC was to create as complete a picture as possible of the most serious human rights violations committed by state agents (people detained-disappeared, executed for political reasons, and tortured to death). Its aim was to collect data in order to identify victims and discover their fate, together with recommending measures for avoiding future human rights violations (Comisión Nacional de Verdad y Reconciliación [CNVR], 1991); it was not allowed to take legal action pertaining to courts of justice. Its report was made public by the President of the Republic at the time, who apologized for the abuse committed. The NTRC reported that 3197 people were killed in Chile for political reasons (this figure includes cases later accepted by the National Reparation and Reconciliation Commission), the armed forces and police being responsible for most of them (CNVR, 1991). After the report was released, a wide-ranging compensation plan was implemented, including pensions for victims' relatives, scholarships for students, and mental and physical health programs (for a 
detailed analysis, see Lira, 2011). As regards collective memory and its symbols, memorials and monuments have been built (most of them thanks to the initiatives of victims' relatives) (Jelin \& Langland, 2003), while as far as justice is concerned, there have been more than 600 trials against agents of the dictatorship, and most of those responsible for the most serious human rights violations have been sent to jail (Lira, 2010).

Psychosocial factors associated with approval for truth commissions

This study deals with predictors of favorable attitudes toward the work of the NTRC. A series of variables or measures relevant in other studies and/or of theoretical importance were selected. These variables were divided into 4 groups: sociodemographic variables and closeness to violence events (including characteristics such as political identification, age, religiousness, and being a victim of violence or a victim's relative); emotional expression and social sharing (emotions arising from remembering NTRC report and extent to which people speak socially about the NTRC work); support for NTRC functions and reparation measures (reading NTRC report, participation in victims' commemoration rituals, perception of NTRC's contribution to revealing the truth and doing justice, to the creation of a comprehensive history and to future violence prevention, and agreement with reparation measures); and institutional factors (positive perception of social climate, institutional trust, and perceived sincerity and effectiveness of official apologies). On the whole, these 4 groups refer to variables that help us to understand the individual's positive or negative appraisal of the NTRC's work.

Sociodemographic variables aim to identify the differences between individuals' positions - that is, to detect whether, 20 years after the release of the NTRC report, personal proximity to violence events is relevant for their appraisal. Part of the sample is made up of individuals who had not been born when the violence events occurred, or even when the report was published, so that age difference may be an important element for understanding the different levels of support for the NTRC's work. Also, in the context of the Chilean dictatorship, participants' political ideas may be an important predictor of support for the NTRC, given the dictatorship's identification with right-wing ideas and victims' identification with left-wing ideas. Support for or rejection of the NTRC work may be attributable to previous symbolic identification with the victims of violence or with its perpetrators (Manzi, 2006). Furthermore, religiousness may strengthen a person's willingness to forgive, in line with the Catholic tradition. Finally, individuals from traumatized families or those directly affected by the violence would be expected to support transitional justice measures more strongly (Aguilar, Balcells, \& Cebolla, 2011), with the extent of violence exposure (from being a direct victim to having relatives or friends who were affected by it) influencing the strength of this factor as a predictor of support for and appraisal of the NTRC work.

However, traumatic events affect not only individuals or their families, but also intermediate groups. For this reason, the second group - emotional expression and social sharingincluded variables such as the extent to which people speak socially about the NTRC work and report. This variable is probably associated with approval of the NTRC's work and a broadening of awareness of the social trauma (Rimé, 2009). In addition, emotions arising from the memories of the period of violence are fundamental for understanding people's actions and appraisals of the NTRC. It is well known that emotions such as guilt and shame encourage the acknowledgement of responsibility and support for reparation measures (DreslerHawke \& Liu, 2006; Etxeberría, Conejero, \& Pascual, 2011), and that others, such as pride and hope, are linked to post-traumatic growth (Vázquez \& Páez, 2011). In any case, truth commission activities produce emotional activation (Kaminer, Stein, Mbanga, \& ZunguDirwayi, 2001; Kanyangara, 2008; Kanyangara, Rimé, Philippot, \& Yzerbit, 2007; Rimé, 
Kanyangara, Yzerbyt, \& Paez, 2011; Stein et al., 2008) and emotional effects in individuals identified as both victims and perpetrators (Brounéus, 2008; Stein et al., 2008).

Support for the NTRC work will also depend on knowledge about its activities and on the extent to which the commission meets the expectations of different social sectors (Beristain et al, 2010). Thus, variables measuring knowledge about the commission and how far it fulfills its functions and achieves its goals were included, dealing with its contribution to revealing the truth and doing justice, and how far it has created a comprehensive history and helped to prevent future cycles of violence; furthermore, agreement with reparation measures is estimated to strengthen support for the NTRC, indicating behavioral agreement with social reconstruction. These variables have been grouped as support for NTRC functions and reparation measures, a category which also includes knowledge about the NTRC activities and report, and the extent to which the person participates in rituals for honoring victims, since such participation may result in greater support for the commission and social recognition of it (Nadler \& Schnabel, 2008; Stroebe \& Stroebe, 1996). In the same line, individuals participating in social movement processes and activities for honoring victims (including, for examples, victims' relatives and human rights workers) are those more likely to exert pressure for the setting up of truth commissions.

Finally, the aim of variables labeled as institutional factors is to detect how the perception of the social climate can condition appraisal of the NTRC work. Thus, a degree of institutional trust is relevant, as it may reveal the conviction that NTRC can provide a way of properly channeling people's demands for truth and justice (despite awareness of the fact that the Chilean commission's authority was restricted with regard to imparting justice). Such trust can also aid the credibility of a comprehensive or inclusive history, which in turn helps make future violence less likely. Also included in this category are variables evaluating the sincerity and effectiveness of official apologies, since, as stated in other studies (Cárdenas, Páez, Arnoso \& Rimé, 2013; Cárdenas, Páez, \& Rimé, 2013; Nadler, Malloy, \& Ficher, 2008; Páez, 2010; Philpot \& Hornsey, 2008), this may be an important requirement for reconciliation and forgiveness among groups, as well as an indicator of acknowledgement of norm transgression (BarTal, 2011).

Using these independent variables may help predict support for the NTRC work. For this reason, a step-by-step logistic regression model is proposed so as to identify how such prediction works. Over twenty-five years, in the case of the CNVR (1991) and thirteen years, in the case of the National Commission on Political Prison and Torture (CNPPT, 2004, for its acronym in Spanish) have elapsed since the creation of the TRC, yet there are no studies that value the impact they had on Chilean society. There are also no studies that report on the variables that could predict a positive evaluation of them in the context of the reconciliation processes between groups in post-conflict zones.

\section{Method}

\section{Sample and procedure}

The sample consisted of 1276 volunteer participants, 623 men $(49.1 \%)$ and 644 women $(50.8 \%)$, with an age range of 18 to 90 years $(\mathrm{M}=39.55$ years and $\mathrm{SD}=17.34)$. Data were collected in the urban areas with the highest population densities: Santiago (26.4 $\%)$, Valparaiso (30.7\%), Concepción (14.5\%), and Antofagasta (28.4\%). The instrument was applied by specially trained university students. Although this was not a random sample, it was stratified so as to reflect the population ratios for sex and different age groups in each city. Once participants had agreed to participate in the study and signed a consent letter informing them of its goals and guaranteeing confidentiality and anonymity (the ethical criteria were those of the National Commission of Science and Technology), they completed the paper-and- 
pencil questionnaire individually. Data were collected between October 2010 and July 2011.

\section{Instrument and variables}

To identify the factors determining attitudes toward NTRC, a dichotomic dependent variable was used according to whether or not an individual approves or disapproves of the NTRC work. As stated above, independent variables were divided into 4 groups related to sociodemographic variables and closeness to events, such as age (how old the individual was at the moment of answering the questionnaire), religiousness (whether or not the individual considered him/herself as religious), political ideas (a 7-level variable, from extreme left to extreme right), and exposure to violence ("Do you consider yourself a victim of violence by the State or its agents in the period 1973 to 1989?" and "Are there victims of violence by the State or its agents in the period 1973-1989 among your relatives or close friends)". For both questions, response options were "Yes" or "No".

The second group of variables included emotions elicited by the Truth and Reconciliation Commission Report (8 basic emotions: sadness/pain, guilt, shame, anger, fear, happiness, pride, and hope; their values ranged from $1=$ "None" to $7=$ "Very much"), together with degree to which one speaks about the events in the report (social sharing) (values ranging from $1=$ "not at all" to $4=$ "a great deal").

The third group included variables related to participants' knowledge about the NTRC report ("Did you read the NTRC report or part of it?"; response options were "Yes" or "No"), and also those pertaining to appraisals of how far the NTRC contributed to relatives' acknowledgement of the truth about their loved ones; justice imparted to human rights violators; created a comprehensive history; and prevented future violence (response options ranged from $1=$ "not at all" to $4=$ "a great deal"). This group also included two questions about participation in victims' commemoration rituals and support for reparation measures (response options for both were "Yes" or "No").

As regards institutional trust (trusting institutions such as the government, political parties, courts of justice, etc.), the variable was dichotomized into "high" and "low", dividing the groups by the scale mean. For positive social climate perception, the 4 items of the CEPN scale (Rivera \& Páez, 2007) were used and two groups were formed on the basis of those who, on the one hand, believed the climate was "not" or "only slightly" positive, and on the other, considered it "quite" or "very" positive. Finally, sincerity and effectiveness attibuted to official apologies were measured ("Do you think these declarations and apologies were sincere?" and "Do you think these declarations and apologies helped society to understand the suffering of groups affected by violence?"), the response options being "Yes" or "No".

\section{Results}

\section{Descriptive data and association tests}

The data indicate that $61.5 \%$ of participants approve of the NTRC work, while $38.5 \%$ disapprove of it; $76 \%$ consider that institutional apologies are not sincere; and $84.3 \%$ think such apologies are ineffective for improving group relations. In addition, most participants have not spoken with other people about the content of the report $(84.7 \%)$, although reparation measures resulting from the report recommendations are well supported $(93.1 \%)$. Concerning political ideas, participants report belonging to the center $(34.4 \%)$, center-left $(24.2 \%)$, and left wing (18.9\%); people defining themselves as center-right account for $11 \%$, and those calling themselves right-wing total $3.8 \%$. Those who trust institutions account for $45.2 \%$ of the sample, and those declaring themselves to be non-religious are $55.6 \%$. Participants defining themselves as victims of State violence amount to $24 \%$ (though associated with different forms of violence, most of which does not correspond 
to that reported by the NTRC). Finally, $54.1 \%$ report having victims among their relatives.

Before including independent variables in the regression model, several association tests were carried out among discrete variables and the dependent variable so as to empirically support the inclusion of each one. Table 1 shows the association coefficient values obtained on crossing independent variables with appraisal of the NTRC work.

\section{TABLE 1}

Association index between independent variables and appraisal of NTRC work

\begin{tabular}{|c|c|c|c|c|}
\hline & $\mathrm{X}^{2}$ & DF & $P$ value & Phi \\
\hline Political identification & 44.73 & 6 & 0 & 0.19 \\
\hline Religiousness & 16.39 & 1 & 0.696 & 0.12 \\
\hline Direct victim & 0.153 & 1 & 0.534 & 0.01 \\
\hline Relative victim & 0.386 & 1 & & 0.02 \\
\hline Speaking about NTRC & 19.34 & 1 & 0 & 0.13 \\
\hline Guilt & 5 & 6 & 0.543 & 0.06 \\
\hline Shame & 7.05 & 6 & 0.316 & 0.08 \\
\hline Happiness & 25.99 & 6 & 0 & 0.15 \\
\hline Pride & 34.96 & 6 & 0 & 0.17 \\
\hline Anger & 36.91 & 6 & 0 & 0.18 \\
\hline Fear & 12.75 & 6 & 0.047 & 0.10 \\
\hline Hope & 114.0 & 6 & 0 & 0.31 \\
\hline Sadness/Pain & 85.16 & 6 & 0 & 0.27 \\
\hline Reading NTRC report & 15.75 & 1 & 0 & 0.11 \\
\hline Participation in commemoration rituals & 0.839 & 1 & 0.360 & 0.01 \\
\hline Contribution to truth & 372.6 & 1 & 0 & 0.56 \\
\hline Contribution to justice & 204.2 & 1 & 0 & 0.41 \\
\hline Comprehensive history & 139.2 & 1 & 0 & 0.34 \\
\hline Future violence prevention & 121.1 & 1 & 0 & 0.32 \\
\hline Agreement with reparation & 28.69 & 1 & 0 & 0.15 \\
\hline Sincerity of apologies & 65.34 & 1 & 0 & 0.23 \\
\hline
\end{tabular}

Almost all variables are significantly associated with appraisal of the NTRC work, except those referring to participation in commemoration rituals, identification as a violence victim, having relatives who identify themselves as victims, guilt, and shame. Thus, having or not having victims among one's relatives and whether or not one considers oneself a victim of the dictatorship may not be determinant criteria for approving or disapproving the work of the NTRC; guilt and shame emotions may also be irrelevant to such approval. These variables will not be included in the regression model, since they are not associated with the dependent variable. For age, the correlation value is significant $\left(\mathrm{r}_{(\mathrm{n}=1208)}=\right.$ $0.15 ; \mathrm{p}<0.05)$ and positive, though rather low.

\section{Logistic regression analysis}

Once the relations among variables had been identified, a step-by-step logistic regression analysis was made for the variable "positive appraisal of the NTRC work". As Table 2 shows, Model 1 includes the set of sociodemographic variables and those referring to proximity to the events; Model 2 adds variables referring to the expression of emotions and social sharing; Model 3 incorporates knowledge about and appraisal of the truth commission's achievements and support for reparation measures; and Model 4 brings in institutional factors.

TABLE 2

Logistic regression: NTRC work approval

\begin{tabular}{|c|c|c|c|c|c|}
\hline & Variables & $\begin{array}{l}\text { Model } 1 \\
B(S D) \\
\end{array}$ & $\begin{array}{l}\text { Model } 2 \\
B(S D) \\
\end{array}$ & $\begin{array}{l}\text { Model } 3 \\
B(S D) \\
\end{array}$ & $\begin{array}{l}\text { Model } 4 \\
B(S D) \\
\end{array}$ \\
\hline \multirow{6}{*}{$\begin{array}{l}\text { Socio- } \\
\text { demographic } \\
\text { variables and } \\
\text { closeness to } \\
\text { violence events }\end{array}$} & Age & $0.018(0.004)^{*}$ & $0.004(0.004)$ & $-0.001(0.006)$ & $-0.001(0.006)$ \\
\hline & $\begin{array}{l}\text { Political } \\
\text { identification }\end{array}$ & $-0.111(0.049)^{*}$ & $-0.019(0.058)$ & $-0.058(0.074)$ & $-0.138(0.079)$ \\
\hline & Religiousness & $0.416(0.129)^{* *}$ & $0.420(0.133)^{*}$ & $0.388(0.163)^{*}$ & $0.240(0.180)$ \\
\hline & $\begin{array}{l}\text { Speaking about } \\
\text { NTRC }\end{array}$ & & $0.426(0.204)^{*}$ & $0.391(0.272)$ & $0.582(0.250)^{*}$ \\
\hline & Guilt & & $-137(0.061)^{*}$ & $-0.163(0.072)^{*}$ & $-0.167(0.072)^{*}$ \\
\hline & Shame & & $-0.054(0.040)$ & $-0.049(0.049)$ & $-0.029(0.050)$ \\
\hline \multirow{8}{*}{$\begin{array}{l}\text { Emotional } \\
\text { expression and } \\
\text { social sharing }\end{array}$} & Happiness & & $-0.008(0.073)$ & $-0.067(0.087)$ & $-0.074(0.092)$ \\
\hline & Pride & & $-0.030(0.062)$ & $-0.030(0.073)$ & $-0.046(0.076)$ \\
\hline & Anger & & $-0.015(0.047)$ & $0.007(0.059)$ & $0.029(0.062)$ \\
\hline & Fear & & $-0.021(0.049)$ & $-0.022(0.060)$ & $-0.007(0.062)$ \\
\hline & Hope & & $0.312(0.043)^{* *}$ & $0.217(0.053)^{* *}$ & $0.190(0.054)^{* *}$ \\
\hline & Sadness/Pain & & $0.181(.033)^{*}$ & $0.159(0.040)^{* *}$ & $0.162(0.043)^{* *}$ \\
\hline & $\begin{array}{l}\text { Contribution to } \\
\text { truth }\end{array}$ & & & $2.08(0.176)^{* *}$ & $2.02(.178)^{* *}$ \\
\hline & $\begin{array}{l}\text { Contribution to } \\
\text { justice }\end{array}$ & & & $0.554(0.190)^{*}$ & $0.513(0.193)^{*}$ \\
\hline \multirow{5}{*}{$\begin{array}{l}\text { NTRC functions } \\
\text { and support for } \\
\text { reparation } \\
\text { measures }\end{array}$} & $\begin{array}{l}\text { Comprehensive } \\
\text { history }\end{array}$ & & & $1.26(0.218)^{* *}$ & $1.27(0.220)^{* *}$ \\
\hline & $\begin{array}{l}\text { Future violence } \\
\text { prevention }\end{array}$ & & & $0.384(0.199)$ & $0.169(0.208)$ \\
\hline & $\begin{array}{l}\text { Agreement with } \\
\text { reparation }\end{array}$ & & & $1.06(0.318)^{* *}$ & $1.17(0.327)^{* *}$ \\
\hline & $\begin{array}{l}\text { Reading NTRC } \\
\text { report }\end{array}$ & & & $0.213(0.296)$ & $0.256(0.304)$ \\
\hline & $\begin{array}{l}\text { Positive social } \\
\text { dimate }\end{array}$ & & & & $0.325(0.178)^{*}$ \\
\hline \multirow{6}{*}{$\begin{array}{l}\text { Institutional } \\
\text { factors }\end{array}$} & $\begin{array}{l}\text { Sincerity of } \\
\text { apologies }\end{array}$ & & & & $0.206(0.249)$ \\
\hline & $\begin{array}{l}\text { Effectiveness of } \\
\text { apologies }\end{array}$ & & & & $0.613(0.238)^{*}$ \\
\hline & Institutional trust & & & & $0.557(0.180)^{*}$ \\
\hline & Constant & $-0.006(0.211)$ & $-1.187(0.181)$ & $-0.871(0.417)$ & $-3.46(0.403)$ \\
\hline & $N$ & 1193 & 1139 & 1120 & 1100 \\
\hline & $\left(\mathrm{CHI}^{2}\right)$ & $42.33^{* *}$ & $153.92^{* *}$ & $505.70^{* *}$ & $530.25^{* *}$ \\
\hline
\end{tabular}

Legend: $* \mathrm{p}<0.05 ; * * \mathrm{p}<0.001$

Source: own work. 
Model 1 highlights the importance of age, political ideas, and religiousness. The results indicate that the older the person, the more to the left they are on the political spectrum and the more importance they give to religious ideas, the greater their approval of the NTRC work. The first two variables tend to lose relevance as variables in the three other groups of factors are added to the subsequent models, religiousness being the most stable variable.

In Model 2, religiousness is still relevant, but the effect of the other variables is lost. Three emotions maintain their effect in the subsequent models. The effect of hope and sadness/pain is positive. Thus, reporting these emotions may be a good predictor for NTRC work appraisal. In contrast, the higher the level of guilt, the lower the approval for the NTRC work. It was also found that the more frequently one speaks about the report's content, the greater the approval for the work of the commission.

Model 3, which adds the extent of people's information about the commission, confirms expectations concerning the importance of religiousness, in addition to revealing the relevance of two other aspects: the fact that the NTRC revealed the truth about what happened to victims and its contribution to creating a comprehensive history including different versions of the past. The model also shows that NTRC contributes to doing justice and punishing those responsible for human rights violations, though these two variables have less weight. A direct relation is revealed between support for reparation measures and appraisal of NTRC work. This may indicate that the greater the support for the NTRC work, the greater the approval of additional reparation measures in favor of victims.

Model 4 incorporates variables dealing with institutional factors, including official apologies. The emotions of sadness/pain, guilt, and hope maintain their relevance; religiousness disappears from the model; and social sharing is added. Thus, variables referring to the NTRC's contribution to finding the truth and creating a comprehensive history still have considerable weight. Contribution to justice remains statistically significant, though its weight is less than that of the two previous variables. The negative effect of support for reparation measures increases its importance in this model. Also, institutional factors are highly relevant, perception of a positive social climate, institutional trust, and perceived effectiveness of official apologies being significant for understanding victims' pain.

\section{Discussion}

Despite the great number of TRCs being initiated around the world, there is little understanding of the long-term effects and the set of variables that could predict a positive evaluation of TRC in post-conflict context. Specifically, currently there are no established mechanisms for measuring the impacts of TRC (Hirsch, McKenzie, \& Sesay, 2012), neither the levels (set of variables) that would be relevant have been established.

Being on the left politically, being older, and religiousness predict NTRC appraisal in the first model. The first two results are coherent with those of other studies (Aguilar et al., 2011). However, these variables are not significant in Model 4, being replaced by less distal variables, though religiousness maintains its predictive capacity in a more stable fashion. Thus, when institutional variables are excluded, a call for reconciliation may evoke restitution in a moral community (reconciliation is the name of a Catholic sacrament), probably based on interpersonal forgiveness parameters (conflict recognition, regret accompanied by the firm intention not to commit sins again, and reciprocal forgiveness based on reparation and expiation of the harm done) (Bagnulo, Muñoz-Sastre, \& Mullet, 2009; Mullet, Nann, Kandiangandu, Neto, \& Pinto, 2011). The fact that institutions connected to the Church, such as Solidarity Vicarage (CNVR, 1991), denounced and documented human rights violations is relevant, since they protected and helped victims. The public recognition of the Catholic Church's role may make identification 
with this category highly relevant and strengthen the positive social identity of religious people as they support ethical measures backed up by their group.

On the other hand, certain emotions appear to play a highly relevant role in predicting attitudes toward the work of the NTRC. Feeling sadness and pain for events, but tinged with hope, seems to be a good predictor of support for truth commissions. Sadness is associated with loss-assimilation behaviors and cognitive reelaboration, while hope involves actively seeking a better future (Fredrickson, 2009). Guilt, unlike in studies on collective guilt (Etxeberría et al., 2011), was found to have a negative effect, which may indicate that when it is present, appraisals of the NTRC work are less favorable. That is, although other research identifies guilt as an emotion producing reparation (Brown, González, Zagefka, Manzi, \& Cehajic, 2008; Manzi et al., 2004), this study shows, rather, that it may constitute a barrier to support for commissions. Since guilt is linked to responsibility for terrible events that nobody wants to take on due to possible effects on their own identity, it may lead to denial and avoidance of facing up to a collective traumatic past. This does not occur with sadness which, though a negative emotion, refers to positive aspects of ourselves insofar as we are able to empathize with victims, showing sensitivity to their misfortune or tragedy.

Speaking about past violence is a good predictor for positive appraisal of the NTRC. Those who feel the greatest need to speak and have spoken the most about a traumatic past probably see the NTRC report as a compendium of horror that permits them to validate their position or inform themselves about the extent of the violence. Those who speak the most about the report may be those with the most knowledge of it, but they may also perceive its content as validated through the confirmation of the facts and events by a "moral authority" in the form of the commission. Thus, speaking with others and remembering the period of violence may predispose people to accept the need for a truth commission, since it brings out emotions such as sadness/pain and hope, which lead to the support for the NTRC work (Bellelli, Leone, \& Cursi, 1999).

Those who most value the NTRC work also consider it to have contributed to revealing the truth about what happened to victims and creating a comprehensive history including the different positions of the actors involved in the conflict. Its contribution to imparting justice is considered substantial, though less relevant than the two previous contributions. Fulfilling certain social functions of collective memory and, to a lesser extent, of justice, are important factors predicting support for truth commissions. Our findings also show that people with a positive attitude toward TCs also think they have contributed more substantially to the creation of a common account of the past, providing information to victims' families, advancing the cause of justice and helping to avoid future violent events. This result suggests that when the commissions' work is regarded as efficient, it facilitates the positive influence of institutional apologies (Cárdenas, Páez, Rimé, \& Arnoso, 2015). Furthermore, as expected, the stronger the support for the NTRC work, the greater the approval of reparation measures. On the other hand, for some people who approve of the commission's work there are still reparation measures pending, and support for such measures is also found in those who disapprove of the NTRC work.

Perceiving the social climate as positive and trusting institutions are excellent predictors of NTRC support. Those who think that the institutions work properly and the social climate is positive are more likely to support the NTRC work. Thus, transitional justice activities are more relevant within contexts where public trust is not severely harmed and institutions operate properly, so that the impartiality of research into the past can be ensured. A TRC can only be successful if the population firmly believes that it can do a serious and honest job, and this is possible only in a climate of institutional trust. If the institutions are discredited, TRC have no chance of being supported (Beristain et al., 2010). Support for NTRC work is also related to the effectiveness attributed to institutional 
apologies as a reflection of the understanding of victims' pain. This may provide a measure of the extent to which the authorities are seen to be truly willing to advance in the quest for truth and become aware of victims' suffering. Without effective apologies, there is no support for TRC (Mullet et al., 2011).

Thus, positive appraisal of the NTRC work depends on the confluence of different variables. The most relevant of such variables appear to be the emotions evoked, sadness/pain and hope being good predictors of positive appraisals of the commission's work. Guilt is connected with rejection of commission work, showing that such work does not always support reparation and may be associated with denial. Support for the NTRC is also based on its contribution to revealing the truth and creating a comprehensive history, together with its perceived success in punishing the guilty. Likewise, social sharing of the past is a significant predictor of support for the commission's work. Lastly, perceiving the social climate as positive, believing that apologies have been effective, and trusting that institutions operate properly are highly relevant factors in relation to support for or rejection of the NTRC work.

The results of the present study provide evidence of social support for the work of the NTRC, regardless of political position or age. This implies that its main effect is on society as a whole, and not only on victims or perpetrators. When the focus falls on society as a whole, the indicators significantly associated with predicting support for the NTRC point to a society that gives value to such efforts and says "never again" to the horrors revealed in the commission's report, regardless of how well it is known or how many people read or analyze it with others.

\section{Acknowledgements}

This article has been funded by the FONDECYT 1140890 project awarded by the National Commission of Scientific and Technological Research (CONICYT).

\section{References}

Aguilar, P., Balcells, L., \& Cebolla, H. (2011). Spaniard's attitudes towards civil war and Francoism's transitional justice measures. Revista Internacional de Sociología, 69(1), 59-90. http://dx.doi.org/10.3989/ ris.2009.06.30

Avruch, K. (2010). Truth and Reconciliation Commissions: Problems in transitional justice and the reconstruction of identity. Transcultural Psychiatry, 47(1), 33-49.

Bagnulo, A., Muñoz-Sastre, M. T., \& Mullet, E. (2009). Conceptualizations of forgiveness: a Latin AmericaWestern Europe comparison. Universitas Psychologica, 8(3), 673-682.

Bar-Tal, D. (Ed.) (2011). Intergroup conflicts and their resolution: Social psychological perspective. New York: Psychology Press.

Bellelli, G., Leone, G., \& Cursi, A. (1999). Emoción y memoria colectiva. El recuerdo de los acontecimientos públicos. Psicología política, 18, 101-124.

Beristain, C., Páez, D., Rimé, B., \& Kanyangara, P. (2010). Psychosocial effects of participation in rituals of transitional justice. Revista de Psicología Social, 25(1), 47-60.

Brahms, E. (2009). What is a truth commission and why does it matter? Peace and Conflict Review, 3(2), 1-14.

Brounéus, K. (2008). Truth-telling as talking cure? Insecurity and retraumatization in the Rwandan Gacaca courts. Security Dialogue, 39(1), 55-76.

Brown, R., González, R., Zagefka, H. Manzi, J., \& Cehajic, S. (2008). Nuestra culpa: Collective guilt and shame as predictors of reparation for historical wrongdoing. Journal of Personality and Social Psychology, 94(1), 75-90.

Cárdenas, M., Páez, D., Arnoso, M., \& Rimé, B. (2013). The perception of the socioemotional climate and institutional trust in victims of political violence: Impact assessment of the National Commission of Truth and Reconciliation. Psykhe, 
22(2), 111-127. http://dx.doi.org/10.7764/ psykhe.22.2.572

Cárdenas, M., Páez, D., \& Rimé, B. (2013). The psychosocial impact of transitional processes in Chile: Assessing the impact of the National Commissions on "Truth and Reconciliation" and "Political Imprisonment and Torture". Revista de Psicología Social, 28, 145-156. http:// dx.doi.org/10.1174/021347413806196717

Cárdenas, M., Páez, D., Rimé, B., \& Arnoso, M. (2015). How transitional justice processes and official apologies influence reconciliation: The case of the Chilean 'Truth and Reconciliation' and 'Political Imprisonment and Torture' Commissions. Journal of Community $\mathbb{E}$ Applied Social Psychology, 26, 515-530. http://dx.doi.org/10.1002/casp.2231

Comisión Nacional de Verdad y Reconciliación. (1991). Informe de la Comisión Nacional de Verdad y Reconciliación [Report of the National Commission on Truth and Reconciliation]. Santiago: Andros.

Comisión Nacional sobre Prisión Política y Tortura. (2004). Informe de la Comisión Nacional sobre Prisión Política y Tortura [Report of the National Commission on Political Prison and Torture]. Santiago, Chile: Gobierno de Chile.

Dresler-Hawke, E., \& Liu, J. H. (2006). Collective shame and the positioning of German national identity. Psicología Política, 32, 131-153.

Etxeberría, I., Conejero, S., \& Pascual, A. (2011). La culpa en contextos de violencia política. In D. Páez, M. Beristain, J. L. González, N. Basabe, \& J. de Rivera (Eds.), Superando la violencia colectiva y construyendo cultura de paz (pp. 39-68). Madrid: Fundamentos.

Fredrickson, B. (2009). Positivity. New York: Crown.

Hayner, P. B. (2001). Unspeakable truths: Confronting state terror and atrocity. New York: Routledge.

Hirsch, M. B., McKenzie, M., \& Sesay, M. (2012). Measuring the impacts of truth and reconciliation commissions:
Placing the global "success" of TRCs in local perspective. Cooperation and Conflict, 47(3), 386-403. http:// dx.doi.org/10.1177/0010836712454273

Jelin, E., \& Langland, I. (2003). Monumentos, memoriales y marcas territoriales [Monuments, memorials and territorial markings]. Buenos Aires: Siglo XXI.

Kaminer, D., Stein, D., Mbanga, I., \& Zungu-Dirwayi, N. (2001). The Truth and Reconciliation Commission in South Africa: relation to psychiatric status and forgiveness among survivors of human rights violations. British Journal of Psychiatry, 178, 373-377.

Kanyangara, P. (2008). Justice et verite apres un genocide : Impact psychosocial sur le pardon et la reconciliation (Doctoral dissertation), Faculté de Psychologie, Louvain, Belgique.

Kanyangara, P., Rimé, B., Philippot, P., \& Yzerbit, V. (2007). Collective rituals, emotional climate and intergroup perception: Participation in Gacaca Tribunals and the assimilation of the Rwandan genocide. Journal of Social Issues, 63, 273-288.

Lira, E. (2010). La reparación a las víctimas: una responsabilidad del Estado. Mensaje, 59, 6-11.

Lira, E. (2011). Verdad, reparación y justicia: el pasado que sigue vivo en el presente. In Instituto Interamericano de Derechos Humanos, Contribución de las políticas de verdad, justicia y reparación a las democracias en América Latina (pp. 85-127). IIDH: San José (Costa Rica).

Manzi, J. (2006). Memoria colectiva del golpe de estado en Chile. En M. Carretero, A. Rosa, \& M. F. González (Eds.), Enseñanza de la historia y memoria colectiva. Buenos Aires: Paidós.

Manzi, J., Ruiz, S., Krause, M., Meneses, A., Haye, A., \& Kronmüller, E. (2004). Memoria colectiva del golpe de Estado de 1973 en Chile. Revista Interamericana de Psicología, 38(2), 153-169.

Mullet, E., Nann, S., Kandiangandu, J., Neto, F., \& Pinto, M. da C. (2011). Hacia una 
política positiva: el caso del perdón en el contexto intergrupal de África y Asia. En D. Páez, M. Beristain, J. L. González, N. Basabe, \& J. de Rivera (Eds.), Superando la violencia colectiva y construyendo cultura de paz (pp. 377-398). Madrid: Fundamentos.

Nadler, A., Malloy, T. E., \& Fisher, J. D. (2008). The social psychology of intergroup reconciliation. Oxford: Oxford University Press.

Nadler, A., \& Schnabel, N. (2008). Instrumental and socioemotional paths to intergroup reconciliation and the need-based model of socio-emotional reconciliation. In A. Nadler, T. E. Malloy, \& J. D. Fisher (Eds.), The Social Psychology of Intergroup Reconciliation (pp. 37-56). Oxford: Oxford University Press.

Páez, D. (2010). Official or political apologies and improvement of intergroup relations: A neo-Durkheimian approach to official apologies as rituals. Revista de Psicología Social, 25(1), 101-115.

Philpot, C. R., \& Hornsey, M. J. (2008). What happens when groups say sorry: The effects of intergroup apologies. Personality and Social Psychology Bulletin, 34, 474-487.

Rimé, B., Finkenauer, C., Luminet, O., Zech, E., \& Philippot, P. (1998). Social sharing of emotion: New evidence and new questions. In W. Stroebe, \& M. Hewstone (Eds.), European Review of Social Psychology (pp. 145-189). Chichester: Wiley \& Sons.

Rimé, B. (2009). Emotion elicits the social sharing of emotion: Theory and empirical review. Emotion Review, 1, 60-85.

Rimé, B., Kanyangara, P., Yzerbyt, V., \& Paez, D. (2011) The impact of Gacaca tribunals in Rwanda: Psychosocial effects of participation in a truth and reconciliation process after a genocide. European Journal of Social Psychology, 41 (6), 695-706.

Rivera De, J., \& Páez, D. (2007). Emotional climates, human security, and cultures of peace. Journal of Social Issues, 63, 233-253.

Sikkink, K., \& Booth Walling, C. (2007). The impact of human rights in Latin America. Journal of Peace Research, 44(4), 427-445.
Stein, D. J., Seedat, S., Kaminer, D., Moomal, H., Herman, A., Sonnega, J., \& Williams, D. R. (2008). The impact of the truth and reconciliation commissions on psychological distress and forgiveness in South Africa. Social Psychiatry and Psychiatric Epidemiology, 43(6), 462-468. http://dx.doi.org/10.1007/ s00127-008-0350-0

Stroebe, W., \& Stroebe, M. (1996). The social psychology of social support. In $\mathrm{T}$. Higgins, \& W. Kruglanski: Social psychology: Handbook of basic principles (pp. 597-622). New York: The Guilford Press.

Vázquez, C. y Páez, D. (2011). Posttraumatic growth in Spain. En T. Weiss \& Berger, R. eds.), Posttraumatic Growth and Culturally Competent Practice: Lessons Learned from Around the Globe (pp. 97-112). New York: Wiley

\section{Notes}

* Research article. 